\title{
ANT LARVAE OF FOUR TRIBES: SECOND SUPPLEMENT \\ (HYMENOPTERA: FORMICIDAE: MYRMICINAE)*
}

\author{
By George C. Wheeler and Jeanette Wheeler \\ Laboratory of Desert Biology \\ Desert Research Institute \\ University of Nevada System \\ Reno, Nevada 89507
}

Subsequent to the publication of our first supplement on the larvae of the subfamily Myrmicinae (1960a) ${ }^{1}$ we have received from other myrmecologists so much additional material that it has become necessary to publish additional supplements.

\section{Tribe Leptothoracini \\ Genus Macromischa Roger \\ Machromischa subditiva Wheeler}

Creighton 1965 - Life cycle: egg 30 days, larva 23 days, pupa 19 days.

\section{Genus Leptothorax Mayr ${ }^{2}$}

Kempf 1959: 393-"The morphological distinctness of the imaginal stages and the distribution of the species may even suggest to accord Nesomyrmex full generic status. The larvae, however, are quite close to the holarctic subgenus Leptothorax s. str., according to G. C. \& J. Wheeler (I955), who studied those of echinatinodis."

\section{Leptothorax carinatus Cole}

SEMIPUPA: Length (through spiracles) about $2.2 \mathrm{~mm}$. Profile probably similar to L. ambiguus (1955:22), otherwise differing in the following details. Body hairs ( $\mathrm{I}$ ) about $0.006 \mathrm{~mm}$ long; (2) 0.006-0.087 mm long; (3) about 0.14 mm long, four on the dorsum of each AI-AIII. Cranium transversely subelliptical. Head hairs 0.012-0.03 mm long, simple or bifid. Ventral border of each lobe of labrum with one isolated and three contiguous sensilla and a few minute spinules. Each labial palp a cluster of five sensilla. (Mate-

*Manuscript received by the editor January 30, 1973

${ }^{1}$ To save space we cite our own papers by year and page; the complete references are in Literature Cited.

${ }^{2}$ In 1950, M. R. Smith changed the well established subgeneric names Leptothorax and Mychothorax to Myrafant and Leptothorax respectively. Could more confusion be generated in less than two pages? The established names should have been conserved. We refuse to accept these changes. 
rial studied: three semipupae from Texas, courtesy of Dr. A. C. Cole.)

\section{Leptothorax hispidus Cole}

WORKER SEMIPUPA. Length (through spiracles) about $3 \mathrm{~mm}$. Similar to L. ambiguus (1955: 22) except as follows. No spinules on integument. Body hairs: ( I) 0.013-0.025 mm long; (2) 0.025$0.068 \mathrm{~mm}$ long; (3) about $0.2 \mathrm{~mm}$ long, four each on AI-AIII. Head hairs 0.015-0.038 mm long, with tip bifid. Labrum with about ten hairs, about $0.025 \mathrm{~mm}$ long, on the anterior surface; posterior surface with eight sensilla. Each maxillary palp a raised cluster of four sensilla; each galea a very short peg with two sensilla. Each labial palp with five sensilla.

YOUNG SEXUAL LARVA. Length (through spiracles) about $\mathbf{3 . 2}$ mm. Similar to the above larva except as follows. Body sac-like. Dorsal surface of posterior somites with a few minute spinules. Cranium transversely subelliptical. Anterior surface of labrum with four hairs.

Material studied: four worker semipupae and two young sexual larvae from Texas, courtesy of Dr. A. C. Cole.

\section{Leptothorax nevadensis Wheeler}

Length (through spiracles) about $2.8 \mathrm{~mm}$. Similar to L. ambiguus (1955: 22) except as follows. Integument with a few minute spinules on the venter of anterior somites and the dorsa of posterior somites. Body hairs: (2) 0.025-0.19 mm long; (3) about $0.25 \mathrm{~mm}$ long, on AI-AIV. Head hairs 0.0I3-0.03 mm long, generally distributed. Each mandible with narrow blade and two medial teeth. Each maxilla with a ventral projection on the lateral surface; each palp a cluster of five sensilla. Each labial palp a cluster of five sensilla. (Material studied: six larvae from Oregon, G. C. and J. Wheeler \# 8)

\section{Leptothorax niger splendidiceps Urbani}

Urbani (I968: 460-464) described the larva and figured young and mature larvae and the head of the latter.

\section{Leptothorax nitens Emery}

Length (through spiracles) about $2.6 \mathrm{~mm}$. Similar to L. ambiguus (1955:22) except as follows. Thorax slightly more constricted and arched ventrally. Integument of venter of anterior somites and dorsa of posterior somites with a few minute spinules, isolated or in short rows. Body hairs: ( I) 0.006-0.012 mm long; (2) 0.025-0.125 mm long; (3) about $0.2 \mathrm{~mm}$ long. Head hairs 0.013-0.05 $\mathrm{mm}$ long, 

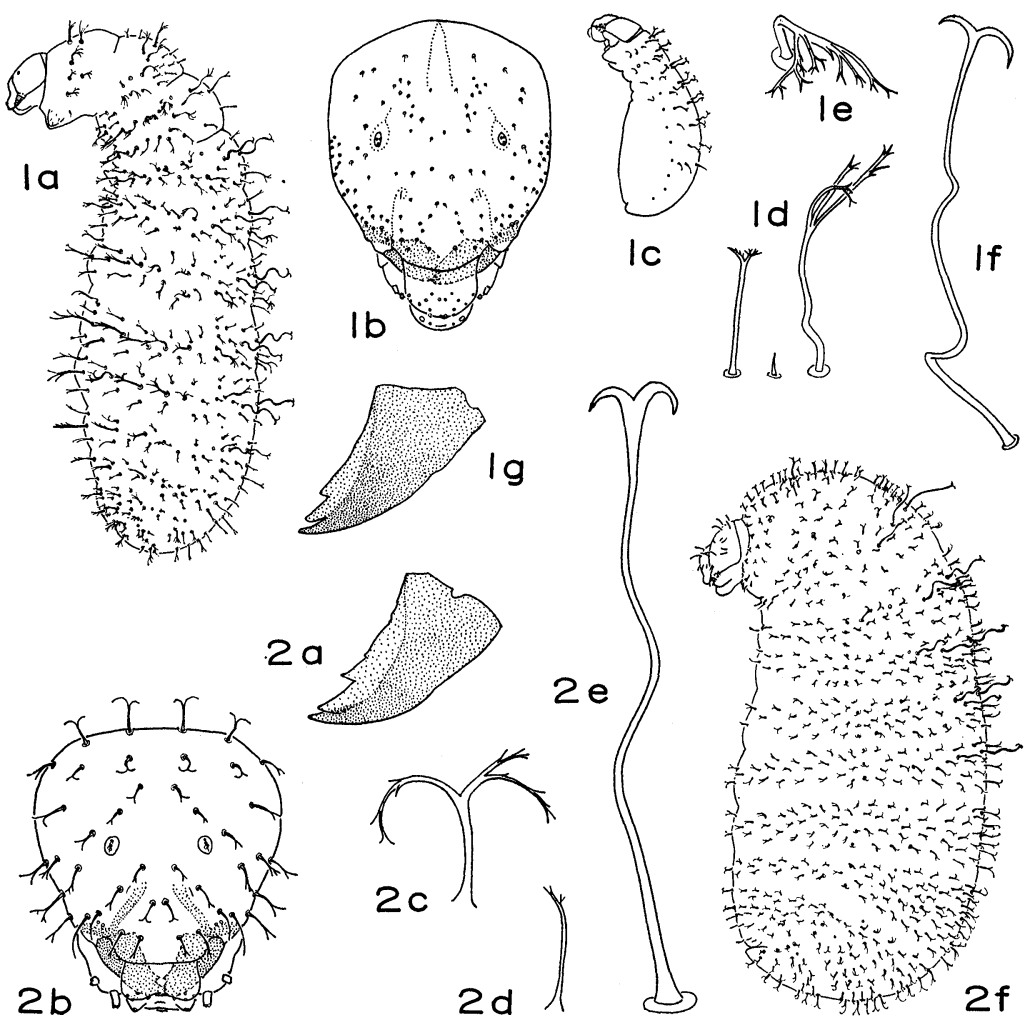

Fig. 1. Leptothorax (M.) provancheri. a, larva in side view, $\times 17$; $b$, head in anterior view, $\times 67$; c, very young larva in side view, $\times 17$; $\mathrm{d}$, simple and branched body hairs, $\times 169$; e, surface view of dendritically branched body hair, $\times 169 ; f$, anchor-tipped body hair, $\times 169$; $g$, left mandible in anterior view, $\times 163$. Fig. 2 . Rogeria procera. a, left mandible in anterior view, $\times 169$; b, head in anterior view, $X 67 ; \mathrm{c}$ and $d$, branched body hairs, $\times 264$; e, anchor-tipped body hair, $X 264 ; f$, larva in side view, $\times 18$. 
simple or bifid. Labrum with eight hairs on the anterior surface; posterior surface with eight sensilla. Each mandible with the blade narrow and bearing two teeth. Each maxillary palp a cluster of four sensilla. Each labial palp a cluster of five sensilla.

VERY YOUNG LARVA. Length (through spiracles) about $1.3 \mathrm{~mm}$. Similar to very young larva of L. ambiguus (1955:23) in shape, otherwise similar to mature larva above except as follows. Cranium more rounded. Head hairs $0.013-0.038 \mathrm{~mm}$ long, all simple. Labrum more narrowed ventrally. Mandibles with narrower blade and sharper teeth. Maxillae very small; each galea a slight elevation with two sensilla.

Material studied: I 5 larvae from Oregon, G. C. and J. Wheeler \# I4.

\section{Leptothorax (Mychothorax) provancheri Emery}

(Fig. I)

Length (through spiracles) about $3.7 \mathrm{~mm}$. Paraponeriform (i.e., shaped somewhat like a crookneck squash; neck short and stout; body elongate, stouter, straight and subcylindrical) ; posterior end rounded; a ventrally projecting boss on each lateral surface of $T_{I}$; each thoracic somite and AI-AIII with a hairless midventral boss. Anus posteroventral. Leg, wing and gonopod vestiges present. Diameter of spiracles decreasing posteriorly. Integument of posterior somites with minute spinules in short rows dorsally and isolated ventrally. Body hairs rather sparse. Of three types: (I) 0.025-0.45 mm long, with straight or kinked shaft and branched (bifid to dendritic) all branches with denticulate tip, on all surfaces of all somites except venter of $\mathrm{T}_{\mathrm{I}}$; (2) 0.025-0.I mm long, simple, on all surfaces of $\mathrm{T}_{\mathrm{I}}$, fewer on $\mathrm{T}_{2}$ and $\mathrm{T}_{3}$; (3) $0.25-0.375 \mathrm{~mm}$ long, anchor-tipped, with curled to kinked shaft, four in a row across the dorsum of each AI-AV (sometimes also one on AVI). Cranium subhexagonal, longer than broad; sides of head nearly straight. Each antenna on a teardropshaped base; each a slight dome with three sensilla, each of which bears a spinule. Head hairs numerous, minute (0.003-0.019 mm long). Labrum paraboloidal in anterior view; anterior surface with I 2 hairs (about $0.012 \mathrm{~mm}$ long), and two sensilla; ventral border with two isolated and two clusters of three sensilla each; posterior surface with about eight sensilla and a few minute spinules in short rows. Mandibles leptothoraciform (i.e., moderately narrow; tapering gradually and curving gradually to an apical tooth; anterior surface produced medially into a blade bearing two subapical teeth); all teeth subequal. Each maxilla with the apex conoidal; each palp 
a short skewed peg with five sensilla; each galea a short frustum with two apical sensilla. Labium narrowly paraboloidal; sparsely spinulose, the spinules minute and in short transverse rows; each palp represented by a cluster of five sensilla; an isolated sensillum between each palp and the opening of the sericteries, the latter a short transverse slit. No spinules on hypopharynx.

VERY YOUNG LARVA. Length (through spiracles) about $1.6 \mathrm{~mm}$. Abdomen sac-like, thorax forming a stout neck. Integument of venter of anterior somites and entire surface of posterior somites with minute spinules. Body hairs sparse. Of three types: (I) o.or3-0.I $\mathrm{mm}$ long, on dorsal and lateral surfaces of thorax and on dorsa of AI-AIV; (2) about $0.006 \mathrm{~mm}$ long, on venter of $\mathrm{TI}$, few on AV: (3) about 0.I mm long, four each on AI-AIV. Antennae minute, each with three sensilla. Head hairs about $\mathrm{I} / 3$ as numerous, minute (0.002-0.005 mm long). Labium subrectangular; anterior surface with about ten sensilla. Mandibles subtriangular in anterior view, with all teeth sharp-pointed. Each maxillary palp represented by a cluster of five sensilla; each galea represented by two contiguous sensilla. Otherwise as in the mature larva.

Material studied: numerous larvae from Colorado, G. C. and J. Wheeler \# 16.

The larva of $L$. provancheri resembles our other species of $M y c h o-$ thorax in profile and in mandible shape, but it differs markedly in the shape of the dominant type of body hair, in the shape of the head, in the shape of the labrum, and in the abundance and size of head hairs.

\section{Genus Rogeria Emery}

Because we had inadequate material previously (1955:28) we are giving a complete description below.

REVISED DESCRIPTION. Profile solenopsidiform. Body hairs moderately abundant; of two types - (I) short, generally distributed and variously branched and (2) anchor-tipped, on mesothorax, metathorax and first three abdominal somites. Head hairs moderately numerous, moderately long and bifid. Mandibles leptothoraciform.

In our 1960b key Rogeria would go to "Monomorium antarcticum" (=Chelaner), from which it cannot be distinguished generically.

\section{Rogeria procera Emery}

(Fig. 2)

Length (through spiracles) about $4 \mathrm{~mm}$. Solenopsidiform (i.e., short and stout; head ventral, near the anterior end; prothorax bent 
ventrally to form a very short stout neck; remainder of body straight; both ends broadly rounded. Anus ventral.) Dorsal profile long and C-shaped; ventral feebly sigmoid. Leg vestiges present. Spiracles small; diameter diminishing posteriorly. Integument of venter of thorax with relatively coarse spinules in transverse rows; a few minute spinules on dorsa of posterior somites. Body hairs moderately abundant. Of two types: ( I ) 0.044-0.I38 mm long, with tip shortbifid to long-branched, the branches variously denticulate or branched; (2) about $0.25 \mathrm{~mm}$ long, anchor-tipped with flexuous shaft, six on the dorsum of each T2, T3, AI, AII and four on AIII. Cranium subtrapezoidal, broadest dorsally; occiput nearly flat; clypeus bulging. Antennae each with three sensilla, each of which bears a rather long spinule. Head hairs moderately numerous, 0.05-0.075 $\mathrm{mm}$ long, bifid with the branches short to long. Labrum bilobed, narrowed dorsally; each lobe with two hairs on the anterior surface about 0.006 $\mathrm{mm}$ long, ventral border with three isolated and two contiguous sensilla, posterior surface with six isolated and a cluster of three sensilla; entire posterior surface with a few short rows of minute spinules dorsally and with coarse isolated spinules ventrally. Mandibles leptothoraciform (i.e., moderately stout, tapering gradually and curving gradually to an apical tooth, anterior surface produced medially into a blade, which bears two medial teeth and a few denticles). Each maxilla paraboloidal, apex with coarse isolated spinules; each palp a cylinder with four apical and one subapical sensilla; each galea a short stout cylinder with two apical sensilla. Labium narrow, anterior surface with coarse spinules, which are isolated or in short rows near each lateral surface; each palp a slight elevation with five sensilla; an isolated sensillum between each palp and the opening of the sericteries, the latter a transverse slit. (Material studied: 12 larvae from Brazil, courtesy of Drs. W. L. Brown and K. Lenko.)

\section{Tribe Ocymyrmecini \\ Genus Ocymyrmex Emery}

Profile aphaenogastriform. Prothorax narrowed rapidly to the diameter of the head. Head small. Anus with a prominent posterior lip. Body hairs numerous, short, with frayed tip. Cranium subcircular. Antennae high on cranium, minute and in pits. Head hairs few, short, with bifid tip. Labrum paraboloidal, as long as broad. Mandibles vollenhoviform but with only one medial tooth.

In our I96ob key this genus would fit under Group D but would require a new rubric: 6 . Body aphaenogastriform (DI); mandibles vollenhoviform (IIf). 


\section{Ocymyrmex arnoldi Forel}

(Fig. 3)

Length (through spiracles) about $5.9 \mathrm{~mm}$. Aphaenogastriform (i.e., stout and rather elongate; diameter greatest at AIV and AV; slightly constricted at $\mathrm{AI}$; thorax stout and arched ventrally, but not differentiated into a neck; posterior end broadly rounded, anus ventral). Prothorax narrowed rapidly to diameter of head. Head small. Anus with a prominent posterior lip. Leg and wing vestiges present. About six differentiated somites. Spiracles small, diminishing slightly posteriorly. Entire integument spinulose, the spinules minute and in short transverse rows, the rows longer and closer together on the venter of the anterior somites. Body hairs abundant, uniformly distributed, all short (0.025-0.075 $\mathrm{mm}$ long), with stout shaft and frayed tip. Cranium subhexagonal; mouth parts rather large. Antennae minute, each in a small pit bounded medially by a high rim, three sensilla each bearing a tall spinule. Head hairs few, short (0.019-0.038 mm long), slightly curved, with short-bifid tip. Labrum paraboloidal, with three small ventral projections; anterior surface with six minute hairs; ventral border with two small sensilla on each ventrolateral projection and two groups of two larger contiguous sensilla; posterior surface with 16 sensilla and scattered minute spinules. Each mandible vollenhoviform, but with only one medial tooth (i.e., slender, rather long and nearly straight, apex forming a moderately long slender tooth which is slightly curved medially; with a narrow medial blade, from the edge of which arises one inconspicuous medial tooth). Each maxilla with the apex paraboloidal and with minute isolated spinules; each palp a narrow frustum with four apical and one lateral sensilla; galea digitiform with two apical sensilla. Labium paraboloidal, with a few short rows of minute spinules; each palp a skewed peg with five sensilla; an isolated sensillum between each palp and the opening of the sericteries, the latter a transverse slit. Hypopharynx with minute spinules in short rows. (Material studied: three larvae and one semipupa from Rhodesia, courtesy of Dr. W. L. Brown.)

\section{Tribe Tetramorini \\ Genus Tetramorium Mayr \\ Tetramorium caespitum (Linnaeus)}

Bruder and Gupta 1972 - Description p. 366; photographs of first, second and third instars and semipupa; drawings of mandibles and maxillae of first, second and third instars. Life cycle in incipient colony : egg 9-12 days, larva 8-I 4 days, semipupa 5 days, pupa I2-I 8 


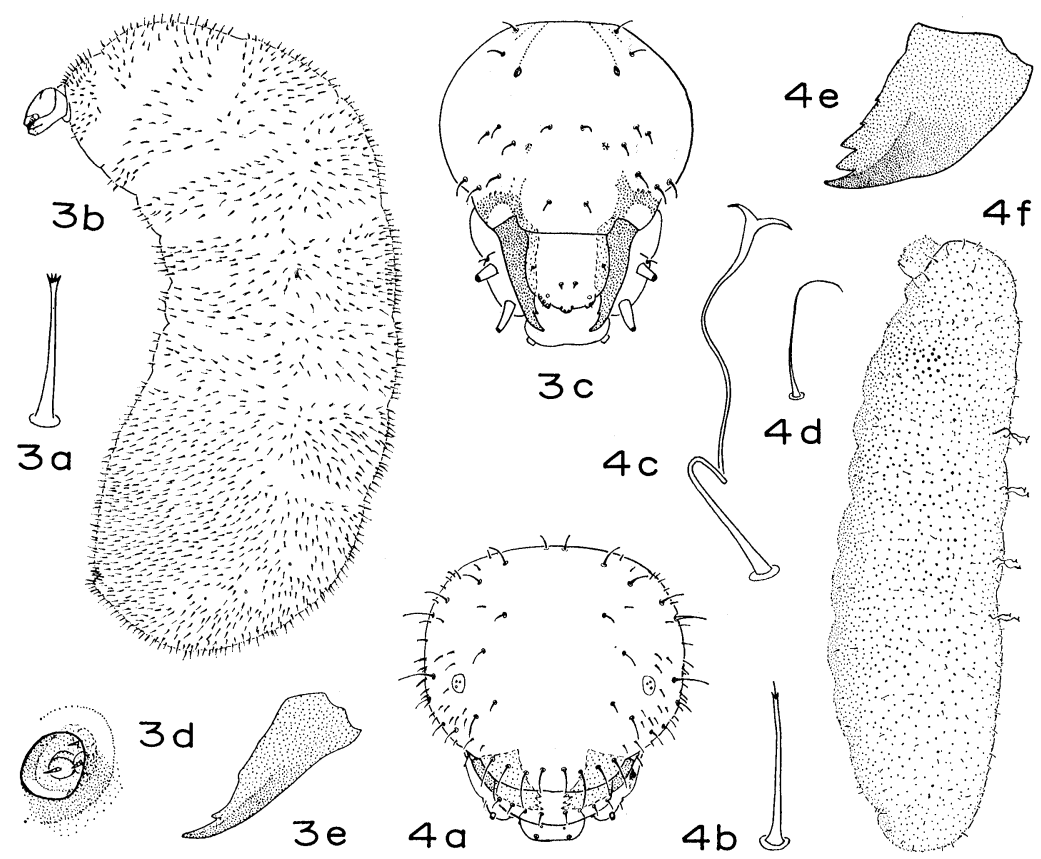

Fig. 3. Ocymyrmex arnoldi. a, body hair, $\times 167$; b, larva in side view, $\times 16$; c, head in anterior view, $X 81$; $d$, right antenna in anterior view, $\times 376$; e, left mandible in anterior view, $\times 133$. Fig. 4. Procryptocerus adlerzi. a, head in anterior view, $\times 67 ; \mathrm{b}-\mathrm{d}$, three types of body hairs, $\times 267$; e, left mandible in anterior view, $\times 185 ; \mathrm{f}$, larva in side view, $\times 14$. 
days, total 36-45 days. Life cycle in mature colonies: egg 8-12 days, first instar 2-7 days, second instar 3-7 days, third instar I0-19 days, semipupa 5 days, pupa I2-1 8 days, total 43-63 days.

\section{Genus TRIgLYPHOThrix Forel \\ Triglyphothrix striatidens Emery}

IMMATURE LARVA. Length (through spiracles) about $2.2 \mathrm{~mm}$. Dorsal profile C-shaped; ventral feebly sigmoid; thorax stout and curved ventrally but not differentiated from abdomen in diameter; abdomen bag-like. Spiracles small; diameter diminishing posteriorly. Integument of venter of anterior somites sparsely spinulose, the spinules minute and in short transverse rows. Body hairs very few: 6 on TI, 2 each on T2-AIV; 0.008-0.033 mm long, longest and with multifid-tip on $T_{I}$, becoming shorter and simple posteriorly. Head large; cranium subpyriform. Each antenna with three sensilla, each of which bears a spinule. Head hairs minute (about $0.006 \mathrm{~mm}$ long), simple, six only, near mouth parts. Labrum twice as broad as long, bilobed, lateral borders curved; each lobe with five sensilla on the anterior surface, two contiguous sensilla on the ventral border, and one isolated and three contiguous sensilla on the posterior surface; entire posterior surface moderately spinulose, the spinules minute and in short rows which are arranged in longer subtransverse rows medially, laterally the spinules are coarser and isolated. Each mandible heavily sclerotized, narrowly subtriangular in anterior view; of two portions: lateral thick and terminating in a long slender apical tooth; medial blade arising from the anterior surface and bearing two sharp-pointed medial teeth. Each maxilla with the apex conoidal and bearing a few spinules; palp a low rounded knob with five sensilla; galea a short frustum with two apical sensilla. Labium feebly bilobed, with minute spinules in subparallel rows; each palp a low rounded knob with five sensilla; an isolated sensillum between each palp and the opening of the sericteries, the latter a short transverse slit. Hypopharynx densely spinulose, the spinules minute and in short arcuate rows which are arranged in long subparallel transverse rows, base with numerous heavily sclerotized longitudinal ridges. (Material studied: numerous immature larvae from New South Wales, courtesy of Rev. B. B. Lowery.)

\section{TRIBE CRYPtocerini ${ }^{3}$}

REVISION: Posterior surface of labrum usually without spinules. Hypopharynx usually without spinules.

\footnotetext{
${ }^{3}$ In 1949, M. R. Smith concluded that the well established name Cryptocerus, which had been in use for 146 years, was a synonym of Cephalotes; he changed Cryptocerini to Cephalotini, Cryptocerus to Paracryptocerus and subgenus Cryptocerus to Harnedia. In four pages could anyone introduce more confusion into stable nomenclature? The old names should have been conserved. We refuse to accept any of these changes.
} 
Genus Cryptocerus Fabricius

Cryptocerus rohweri Wheeler

Creighton and Nutting 1965: 63-"Worker brood developed from egg to adult in about three months (egg to larva \pm 27 days; larva to pupa \pm 33 days; pupa to adult \pm 23 days)." Eggs developed in about a month into male larvae, which overwintered.

\section{Cryptocerus (Cyathomyrmex) pallens Klug}

IMMATURE LARVA. Length (through spiracles) about $3.4 \mathrm{~mm}$. Similar to C. minutus (called Paracryptocerus minutus in 1954: I55) except as follows. Head very large and covering approximately half of the anterior end. Integument of venter of anterior somites and all surfaces of posterior somites with a few minute spinules in short transverse rows. Body hairs: (I) $0.006-0.038 \mathrm{~mm}$ long, most numerous on the prothorax; (2) about $0.225 \mathrm{~mm}$ long. Head hairs very numerous, slightly longer (0.013-0.05 mm long). Anterior surface of labrum with eight hairs and/or sensilla. Mandibles moderately to feebly sclerotized. An isolated sensillum between each palp and the opening of the sericteries.

VERY YOUNG LARVA. Length (through spiracles) about $1.6 \mathrm{~mm}$. Body subellipsoidal, head on the anterior end (i.e., similar to $1.9 \mathrm{~mm}$ larva of $C$. minutus, 1954: I55). Otherwise similar to mature larva except in the following details. Entire integument spinulose, the spinules minute and in short transverse rows. Head hairs shorter (0.013-0.038 $\mathrm{mm}$ long). Labrum with ten hairs on the anterior surface. Mandibles sickle-shaped, no blade.

Material studied: five larvae from Brazil, courtesy of Dr. K. Lenko.

\section{Genus Procryptocerus Emery}

REvision. Profile cataulaciform. Body hairs moderately numerous. Of three types: (I) simple with flexuous tip; (2) tip shortbranched, multifid; (3) anchor-tipped. Head hairs of two types: (I) simple, with long flexuous tip; (2) with short-branched (multifid) tip. Mandibles cryptoceriform. Posterior surface of labrum with or without spinules. Maxillae adnate and rounded. Hypopharynx with or without spinules.

\section{Procryptocerus adlerzi (Mayr)}

(Fig. 4)

Length (through spiracles) about $4.6 \mathrm{~mm}$. Profile cataulaciform (i.e., straight, elongate-subelliptical; segmentation indistinct; head applied to the ventral surface near the anterior end); no neck. Anus ventral, with a posterior lip. Leg, wing and gonopod vestiges present. 
Six feebly differentiated somites. Spiracles small; decreasing in diameter posteriorly. Integument of ventral surface of anterior somites with minute spinules in short transverse rows, entire surface of posterior somites with scattered minute spinules. Body hairs moderately numerous. Of three types: (I) 0.013-0.036 mm long, simple, tip very fine and flexuous; (2) 0.022-0.13 mm long, tip denticulate, a few on each somite; (3) about $0.2 \mathrm{~mm}$ long, with flexuous shaft and anchortip, four on each AI-AIV. Cranium subcircular in anterior view. Antennae moderately large; just below middle of cranium; each with three small sensilla, bearing a spinule each. Head hairs moderately numerous, short to moderately long. Of two types: ( I ) o.org-0.03 $\mathrm{mm}$ long, simple, with long fine flexuous tip, the more numerous type; (2) 0.028-0.075 $\mathrm{mm}$ long, with short-branched tip. Labrum arcuate; with eight hairs $0.025-0.038 \mathrm{~mm}$ long; ventral border with four isolated and two clusters of three sensilla each; posterior surface with four isolated and two clusters of three sensilla each; spinules lacking. Mandibles cryptoceriform (i.e., stout, subtriangular in anterior view; lateral portion thick and terminating in a sharp-pointed apical tooth; medial blade arising from the anterior surface and bearing two subapical teeth, which are subequal to apical tooth). Maxillae rounded and adnate; each palp a short peg with five sensilla, larger than the galea, the latter a short cylinder with two apical sensilla. Labium small; each palp a short stout peg with five sensilla; an isolated sensillum between each palp and the opening of the sericteries, the latter a short transverse slit. No spinules on hypopharynx.

IMMATURE LARVA. Length (through spiracles) about 3.I mm. Body relatively stouter. Head on anterior end. Integument of dorsal surface of posterior somites with rather coarse spinules. Body hairs ( I) 0.025-0.05 mm long; (2) 0.019-0.125 mm long; (3) about $0.225 \mathrm{~mm}$ long, four on the dorsal surface of each AI-AIV. Otherwise similar to mature larva.

VERY YOUNG LARVA. Estimated length about I.4 mm. Similar to the immature larva except as follows. Body hairs sparse: (I) 0.002-0.025 mm long; (2) 0.024-0.05 mm long, with tip denticulate to flattened; (3) about $0.086 \mathrm{~mm}$ long, on AI-AVI. Head hairs sparse, all short spikes (about $0.003 \mathrm{~mm}$ long). Anterior surface of labrum with six hairs about $0.006 \mathrm{~mm}$ long. Each mandible with the apex turned medially; all teeth narrowly sharp-pointed. Each labial palp represented by a cluster of five sensilla.

Material studied: I4 larvae from Brazil, courtesy of Dr. K. Lenko. 


\section{Procryptocerus regularis Emery}

Length (through spiracles) about $5.4 \mathrm{~mm}$. Similar to $P$. adlerzi except as follows. Body stouter; head relatively larger. Integument with few spinules on the anterior somites. Body hairs ( I) o.or3$0.05 \mathrm{~mm}$ long; (2) 0.038-0.II3 mm long; (3) four on the dorsa of each AI-AIV. Cranium transversely subelliptical. Antennae larger. Head hairs numerous; ( I) 0.007-0.05 mm long; (2) 0.038$0.087 \mathrm{~mm}$ long. Labrum feebly bilobed, with eight hairs 0.013-0.05 $\mathrm{mm}$ long; each lobe with six isolated and two contiguous sensilla on and near the ventral border; entire posterior surface with a few transverse rows of minute spinules. Each mandible with apical tooth longer and basal teeth shorter. Each galea represented by two contiguous sensilla. Each labial palp represented by a cluster of five sensilla. Hypopharynx with a few transverse rows of minute spinules.

YOUNG LARVA. Length (through spiracles) about $1.8 \mathrm{~mm}$. Similar to mature larva except as follows. Entire integument with minute spinules, in short rows anteroventrally, elsewhere isolated, coarsest posteriorly. Body hairs sparse; ( I) $0.003-0.044 \mathrm{~mm}$ long; (2) 0.013-0.088 mm long; (3) 0.125-0.188 mm long. Head hairs moderately numerous, $0.003-0.044 \mathrm{~mm}$ long, simple. Hairs on labrum about $0.003 \mathrm{~mm}$ long.

YOUNGEST LARVA. Length (through spiracles) about I $\mathrm{mm}$ long. Similar to young larva except as follows. Body egg-shaped. Spiracles very small. Integument with spinules on the dorsal surface of abdomen from spiracle to spiracle, more extensive on AIX and AX. Body hairs very sparse; ( I ) 0.003-0.025 mm long, few, none on AIX and AX: (2) 0.025-0.075 mm long, few, with short-bifid to short-multifid tip, on lateral surfaces; (3) 0.09-0. $8 \mathrm{~mm}$ long, four on the dorsum of each AI-AVII, with straight shaft and smooth anchor-tip. Head hairs very few, about $0.003 \mathrm{~mm}$ long. Posterior surface of labrum lacking spinules. Each mandible with one apical and one medial tooth. Each maxillary palp represented by a cluster of sensilla. Labium and hypopharynx without spinules.

MALE LARVA. Length (through spiracles) about $5.8 \mathrm{~mm}$. Similar to worker larva except as follows. Thirteen feebly differentiated somites. Body hairs (3) about 0.15 $\mathrm{m} \mathrm{m}$ long, four on the dorsal surface of each AI-AIV. Cranium subrectangular. Head hairs ( I) O.OI $3 \mathrm{~mm}$ long; (2) about $0.38 \mathrm{~mm}$ long, with short-bifid tip, about eight on the cranium. Mandibles heavily sclerotized.

Material studied: numerous larvae from Brazil, courtesy of Dr. K. Lenko. 


\section{Procryptocerus striata scabriuscula Emery}

Length (through spiracles) about $5.2 \mathrm{~mm}$. Similar to $P$. adlerzi except as follows. Body stouter. Integument of venter of anterior somites and dorsa of posterior somites with minute spinules in short transverse rows. Body hairs ( I) 0.003-0.19 mm long, spike-like; (2) 0.013-0.05 mm long, very few on each somite. Cranium transversely subelliptical. Head hairs few. Labrum with six hairs and six isolated and two clusters of three sensilla each on the anterior surface; posterior surface with six isolated and two clusters of two or three sensilla each and with minute spinules in short arcuate rows, the rows forming a reticulate pattern. Mandibles quadrilateral, heavily sclerotized, with all teeth straight and round-pointed. Each maxillary palp an ungula, with two apical and three lateral sensilla; each galea a very short stout peg with two apical sensilla. (Material studied: nine larvae from Mexico, courtesy of Roy R. Snelling.)

\section{Literature Cited}

BRUder, K. W., AND A. P. GuPtA

1972. Biology of the pavement ant, Tetramorium caespitum. Ann. Entomol. Soc. Amer. $68: 358-367$.

Creighton, W. S.

1965. The habits and distribution of Macromischa subditiva Wheeler. Psyche 72: 282-286.

Creighton, W. S., and W. L. Nutring

1965. The habits and distribution of Cryptocerus rohweri Wheeler. Psyche 72: 59-64.

KEMPF, W. W.

1959. A synopsis of the New World species belonging to the Nesomyrmex-group of the ant genus Leptothorax Mayr. Studia Entomol. (Rio de Janeiro) 2: 291-432.

SMITH, M. R.

1949. On the status of Cryptocerus Latreille and Cephalotes Latreille. Psyche 56: 18-21.

1950. On the status of Leptothorax Mayr and some of its subgenera. Psyche 57: 29-30.

URBANI, C. B.

1968. Studi sulla mirmecofauna d'Italia. IV. La fauna mirmecologico delle isole maltesi ed il suo significato ecologico e biogeografico. Ann. Mus. Civ. Stor. Nat. Genova $77: 408-559$.

WheEler, G. C., AND JeANETte WheELER

1954. The ant larvae of the myrmicine tribes Cataulacini and Cephalotini. J. Washington Acad. Sci. 44: 149-157.

1955. The ant larvae of the myrmicine tribe Leptothoracini. Ann. Entomol. Soc. Amer. 48 : 17-29.

1960a. Supplementary studies on the larvae of the Myrmicinae. Proc. Entomol. Soc. Washington 62: 1-32.

1960b. The ant larvae of the subfamily Myrmicinae. Ann. Entomol. Soc. Amer. 53 : 98-110. 

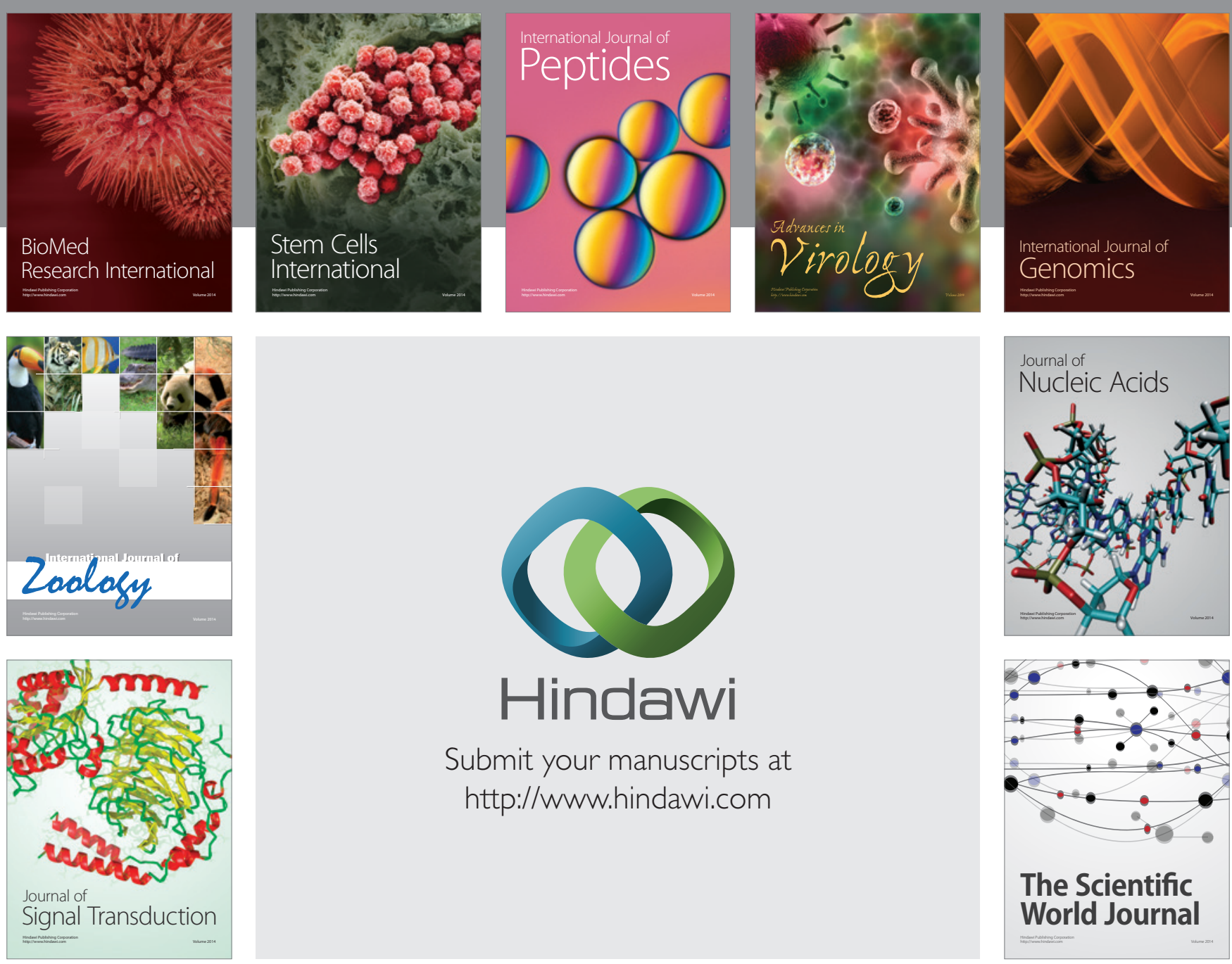

Submit your manuscripts at

http://www.hindawi.com
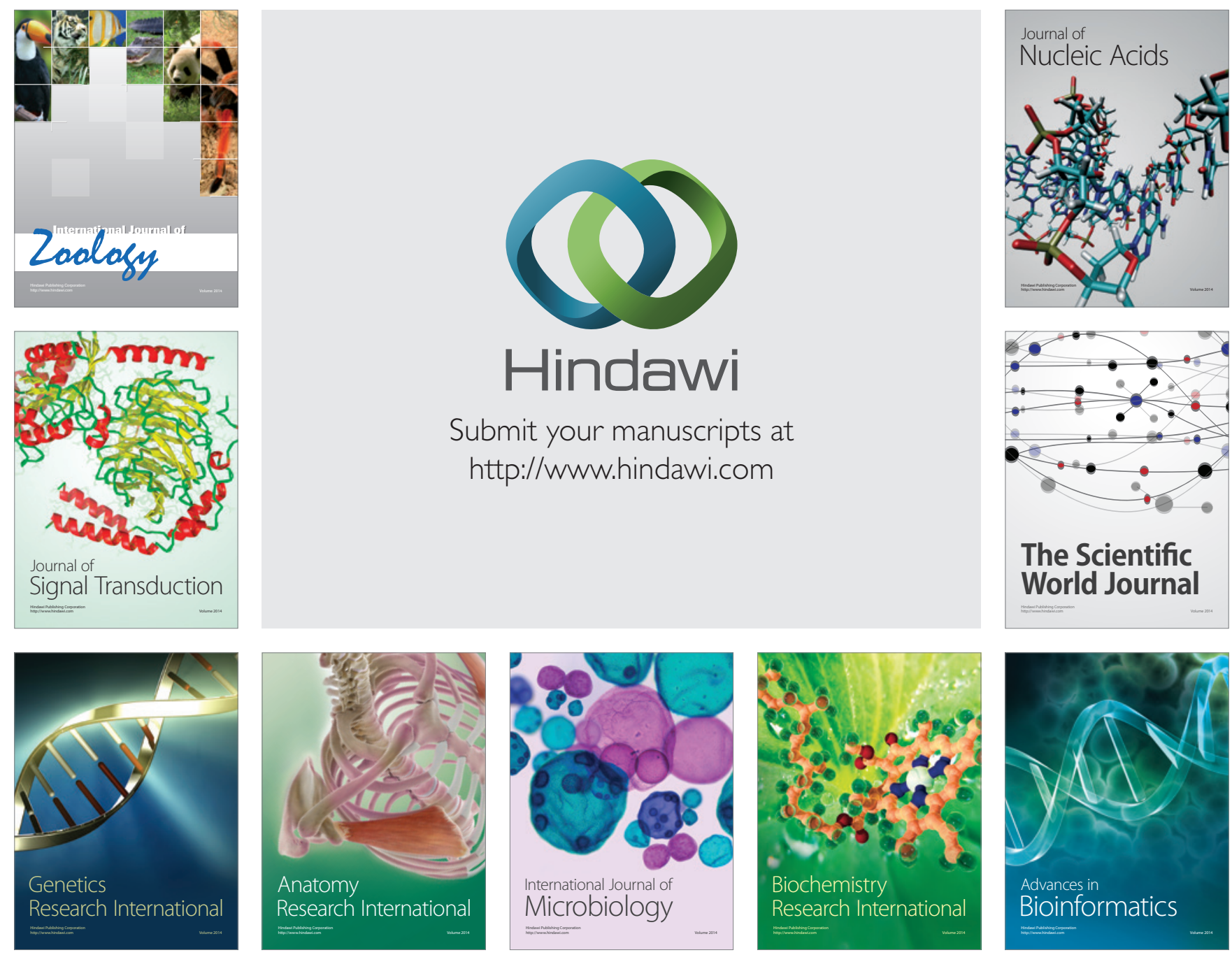

The Scientific World Journal
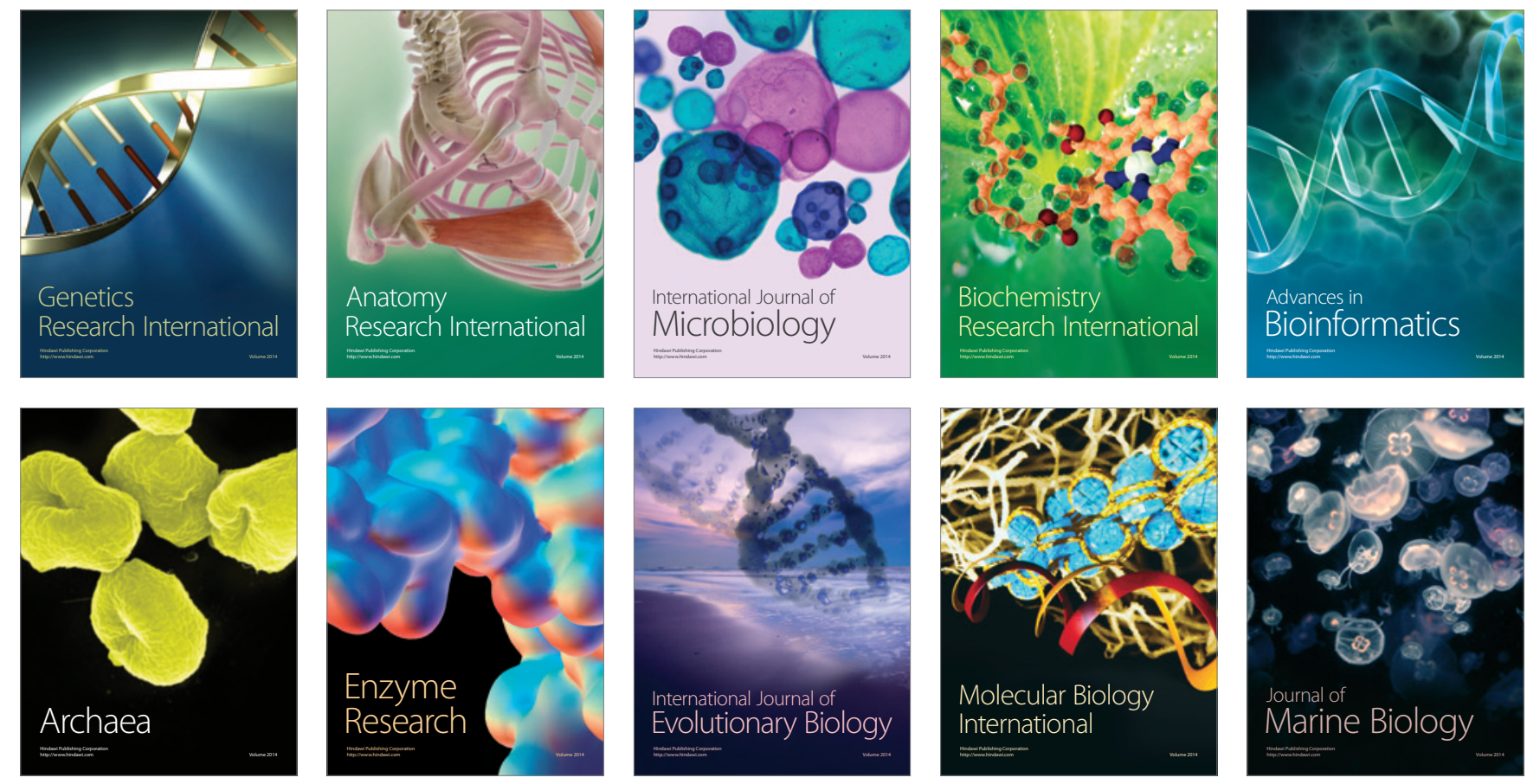